\title{
Efficiency of the breeding use of the genus Prunus L. biodiversity
}

\author{
R.Sh. Zaremuk, Yu.A. Dolya, T.A. Kopnina*, and A.A. Kochubey \\ Federal State Budgetary Scientific Institution "North Caucasus Federal Scientific Center of \\ Horticulture, Viticulture, Winemaking" (FSBSI NCFSCHVW), Krasnodar, Russia
}

\begin{abstract}
Preservation and search of the source material of the Prunus L. gene pool for breeding, especially in contrasting weather conditions, it becomes particularly relevant. Breeding collection of representatives of the genus Prunus L. NCFSCHVW: sweet cherry (Prunus avium L.), common cherry (Prunus cerasus L.), plum (Prunus domestica L.), has more than 500 samples and is the basis for improving the genotypes of stone fruit plants. The purpose of the research is to evaluate the breeding potential of stone crops and to identify unique variety forms for new varieties creation. The paper presents donors and sources of important traits: early fruitfulness, winter hardiness, drought resistance, resistance to Coccomyces hiemalis Higg., Monilia cinerea, large fruitfulness and productivity, and substantiates their importance in ensuring the further breeding process and updating the gene pool of stone crops. The best varieties, primarily of domestic breeding, with specific characteristics for integration into new breeding programs are selected: sweet cherry - Madonna, Kavkazskaya Uluchshennaya, Volshebnitsa, Cherniye Glaza, Alaya and Mak; cherry Krasnodarskaya Sladkaya, Kazachka, Kirina Kubanochka, Alexa; plum Prikubanskaya, Krasnodarskaya, Milena, Podruga, Charodeyka, Krasotka, Gertsog.
\end{abstract}

\section{Introduction}

The problem of conservation and rational use of genetic resources is of global importance. This is evidenced by the programs of international organizations (FAO, UNDP, ECCDS, IPGRI, EUCARPIA, ECPGR, AEGIS, EURISCO, etc.), co-implemented by Russia, having unique collections of agricultural plants [1,2]. Even N.I. Vavilov identified one of the main tasks for solving the problem of food security of mankind - the maintenance and study of cultivated plants collections, the identification of genetic sources and the creation of adaptive varieties on their basis [3]. According to the Convention on Biodiversity, each species, ecotype, and local variety is a unique transition to an ecologicalbiosphere strategy [1,4]. There is no doubt that the study of the Prunus L. gene pool under stressful conditions and an extremely changing climate is of particular relevance [5]. In this connection, the "North Caucasus Federal Scientific Center of Horticulture and Viticulture" preserves and annually replenishes the collection of fruit stone plants, which includes more

\footnotetext{
* Corresponding author: tatjanakopnina@rambler.ru
} 
than 500 varieties of sweet cherry (Prunus avium L.), common cherry (Prunus cerasus L.), plum (Prunus domestica L.) of various ecological and geographical origin (Canada, USA, Italy, France, England, Germany, America, Czech Republic, Belarus, Moldova, Ukraine, etc.). The gene pool is stored in the field, from three to five or more samples of each genotype. Based on the relevance of assessing the genetic variability of collections, the purpose of the study is to assess the breeding potential of stone crops and identify unique variety forms for new varieties creation.

\section{Materials and Method}

Evaluation of the effectiveness of stone crop collections use allowed to conclude that hybridization was carried out according to breeding programs developed for each crop, which allowed to identify donors, sources and create genotypes with improved traits $[3,6]$. Thus, breeding for large-fruitness, fruit quality, adaptability and productivity, with the involvement of the best donors and sources of valuable biological traits remains the main directions for plum $[4,7]$.

\section{Results and Discussion}

The evaluation of varieties as parental forms in plum breeding showed that more often varieties of Izyum Kubansky, Persikovaya, Vengerka Italyanskaya, Vengerka Azhanskaya, Renklod Zeleny, Veliky Gertsog, Stanley, Kabardinskaya Rannyaya, etc. were used in the crosses. And on their basis, Russian varieties were created: Krasnodarskaya (Vengerka Azhanskaya $\times$ Veliky Gertsog), Prikubanskaya (Vengerka Azhanskaya x Renklod Zeleny), Milena (Izyum Kubansky $\times$ Vengerka Italyanskaya), Krasotka (Kabardinskaya Rannyaya $\times$ Stanley).

To increase fruit weight, large-fruited varieties of plum Veliky Gertsog, Persikovaya, Kabardinskaya Rannyaya, Stenley were taken as parental forms in the breeding, which made it possible to create genotypes with relatively large fruits, the weight of which varied from 38.3 to $50.5 \mathrm{~g}$. These are the Gertsog (Metelka $\times$ pollen mix of Veliky Gertsog+Persikovaya), Charodeyka (Anna Shpet $\times$ pollen mix of Stanley+Kabardinskaya Rannyaya), Milena (Izyum Kubansky $\times$ Vengerka Italyanskaya), Podruga (Vengerka Azhanskaya $\times$ Veliky Gertsog), Krasotka (Kabardinskaya Rannyaya $\times$ Stanley) varieties. The results obtained allowed to identify inheritance patterns of the large-fruited trait by plum progeny, indicating that when crossing both parental forms with large-sized fruits, there is a split with a predominance of hybrid seedlings with an average fruit weight of $39.5 \%$, the share of large-fruited seedlings was $31.2 \%$, seedlings with small fruits $-29.3 \%$. It was found that heritability coefficient of large fruit size in plum varieties is high and is 0.55 , the coefficient of variation is $39.2 \%[1,4]$. The revealed inheritance patterns of taste qualities by plum progeny allow to state that most of the new genotypes of plum had fruits with taste qualities lower than those of the original parental forms. According to the data obtained, only about $36.0 \%$ of plum hybrids inherit the high taste qualities of the parental cultivars. More than $50 \%$ of hybrid seedlings are characterized by low fruit quality indicators. Thus, domestic varieties of plum Milena, Gertsog, Charodeyka, Podruga are characterized by fairly high taste qualities of the fruit inherited from the parental forms of Izyum Kubansky, Veliky Gertsog, Anna Shpet, Kabardinskaya Rannyaya and Stanley (Table 1).

From the above, it can be summarized that the use of a limited number of varieties in directed crosses greatly narrows the genetic diversity, in particular of plum. With this in mind, the collection is annually replenished with varieties of various origins, including 
native, wild samples, which makes it possible to replenish the invaluable reserve of useful genes and widely involve them in hybridization. The study of the breeding potential of plum varieties collection allowed to identify donors and sources of significant traits for introgression in the new generation varieties presented in Table 1.

Table 1. Source material for priority breeding programs for plum (Prunus domestica L.), (city of Krasnodar, NCFSCHVW General Collection)

\begin{tabular}{|l|l|}
\hline \multicolumn{1}{|c|}{ Valuable traits } & \multicolumn{1}{|c|}{ Donors, sources } \\
\hline Large-fruitness & $\begin{array}{l}\text { Crimson Glo, Dark Sunlight, August Delight, Blue Moon, Big Stanley, } \\
\text { Stanley, Kabardinskaya Rannyaya, Chernosliv Adygeysky, Milena, } \\
\text { Charodeyka, Gertsog }\end{array}$ \\
\hline $\begin{array}{l}\text { Taste and } \\
\text { marketability of } \\
\text { fruits }\end{array}$ & $\begin{array}{l}\text { Big Stanley, Dark Sunlight Stanley, Kabardinskaya Rannyaya, } \\
\text { Chernosliv Adygeysky, Nectar, Milena, Krasotka, Gertsog }\end{array}$ \\
\hline $\begin{array}{l}\text { Drought and heat } \\
\text { resistance }\end{array}$ & $\begin{array}{l}\text { Big Stanley, Stanley, Balkarskaya, Asker, Turchanka, Chachakskaya } \\
\text { Pozdnyaya, Chachakskaya Uluchshennaya, Gertsog, Charodeyka }\end{array}$ \\
\hline Yield & $\begin{array}{l}\text { Crimson Glo, Blue Moon, Dark Sunlight Stanley, Kabardinskaya } \\
\text { Rannyaya, Chernosliv Adygeysky, Preedgornaya, Balkarskaya, Gertsog, } \\
\text { Charodeyka, Prikubanskaya }\end{array}$ \\
\hline
\end{tabular}

The priority areas in cherry breeding are large-fruitness, taste qualities and resistance to major diseases [8]. Evaluation of collection varieties use showed that in cherry breeding, a limited number of parental forms were also used. These are mainly varieties of Kistevaya, Vladimirskaya, Chernokorka, Nord Star, Molodezhnaya, Igrushka, Vstrecha, etc. Nevertheless, it should be noted that along with hybridization, the method of induced mutagenesis was often used in cherry breeding, on the basis of which domestic varieties Kubanochka (hemomutant of the Kistevaya variety (Vladimirskaya x ground cherry), Alexa (mutagen of the Kirina variety (Vladimirskaya sv. op. x Ramon Oliva) were obtained [4]. It is known that as a result of induced mutagenesis, hybrids with a late maturation period, with small fruits and low taste qualities are more often distinguished. Nevertheless, it should be noted that the local varieties Alexa and Kubanochka, obtained by this method, belong to the group of medium-term maturation, have large fruits weighing 5-7 $\mathrm{g}$ and are characterized by high taste qualities, i.e. "surpassed" the original forms in a number of indicators. The use of interspecific hybridization of cherries allowed to increase the resistance to abiotic factors. Thus, the inclusion of steppe cherry $\left(P\right.$. fruticosa) in the $\mathrm{F}_{2}$ generation in the crossing caused increased frost resistance (up to $-28^{\circ} \mathrm{C}$ ) of the Kubanochka variety. Intervariety crosses involving the varieties Nord Star (Canada), Vladimirskaya (Russia), Chernokorka (Ukraine) of various ecological and geographical origin also allowed to obtain high-winter-hardy varieties Kazachka (Chernokorka x sweet cherry pollen mix), Nostra (a clone of the Nord Star variety). To improve the taste of new cherry varieties, hybridization included dukes that were superior in fruit quality to varieties of typical cherry, as well as sweet cherry varieties. According to these schemes, the varieties of Kazachka and Alexa were obtained, combining in their genotype the characteristics of dukes and the best cherry varieties. They are characterized by a high content of dry matter at the level of $16.8 \%$, sugars - $7.9 \%$ and a low content of various acids, in the range of $1.5-1.7 \%$.

The evaluation of the common cherry genetic collection also made it possible to identify the best source material for the implementation of modern breeding programs (Table 2). 
Table 2. Source material for priority breeding programs of common cherry (Prunus cerasus L.), (city of Krasnodar, NCFSCHVW General Collection)

\begin{tabular}{|l|l|l|}
\hline Trait & Donors and sources & Domestic varieties \\
\hline Winter hardiness & $\begin{array}{l}\text { Shokoladnitsa, Kazachka, Shokoladnitsa, } \\
\text { Orlitsa, Turgenevka, Nefris, Konkurentka, } \\
\text { Prevoskhodnaya Kolesnikovoy }\end{array}$ & $\begin{array}{l}\text { Chocolate girl, Eagle, } \\
\text { Turgenevka, Competitor, Nostra, } \\
\text { Prevoskhodnaya Kolesnikovoy, } \\
\text { Alexa, Kubanochka, Kazachka }\end{array}$ \\
\hline $\begin{array}{l}\text { Drought } \\
\text { resistance }\end{array}$ & $\begin{array}{l}\text { Timati, Duke Khodosa, Vstrecha, Duke } \\
\text { Ivanovna }\end{array}$ & Kirina, Kazachka, Feya \\
\hline $\begin{array}{l}\text { Resistance to } \\
\text { coccomycosis }\end{array}$ & $\begin{array}{l}\text { Novella, Molodezhnaya, Dombaziya, Feya, } \\
\text { Elegiya, Juicy Fruit, Vstrecha, Timati, } \\
\text { Orotak, Duke Ivanovna }\end{array}$ & $\begin{array}{l}\text { Novella, Molodezhnaya, Feya, } \\
\text { Alexa, Kubanochka }\end{array}$ \\
\hline $\begin{array}{l}\text { Resistance to } \\
\text { moniliosis }\end{array}$ & $\begin{array}{l}\text { Novella, Shalunya, Igrushka, } \\
\text { Molodezhnaya, Turgenevka, Juicy Fruit }\end{array}$ & $\begin{array}{l}\text { Kirina, Alexa, Kubanochka, } \\
\text { Novella, Molodezhnaya }\end{array}$ \\
\hline Early maturity & $\begin{array}{l}\text { Prizvaniye, Igrushka, Nefris, Fanal, Duke } \\
\text { Ivanovna }\end{array}$ & $\begin{array}{l}\text { Krasnodarskaya } \\
\text { Kazachka }\end{array}$ \\
\hline Low growth & $\begin{array}{l}\text { Krishana, Malyshka, Molodezhnaya, } \\
\text { Orlitsa, Turgenevka, Tamaris, Feya }\end{array}$ & $\begin{array}{l}\text { Kazachka, } \\
\text { Sladkaya, Molodezhnaya, }\end{array}$ \\
\hline Yield & $\begin{array}{l}\text { Duke Ivanovna, Molodezhnaya, Nefris, } \\
\text { Novella, Shalunya, Shokoladnitsa, } \\
\text { Hombaziya, Orotak, Igrushka, Duke }\end{array}$ & $\begin{array}{l}\text { Kazachka, } \\
\text { Krasnodarskaya Sladkaya }\end{array}$ \\
\hline High fruit quality & $\begin{array}{l}\text { Chudo-vishnya, Krupnoplodnaya, Duke } \\
\text { Hodosa, Prizvaniye, Dombaziya, Vstrecha }\end{array}$ & $\begin{array}{l}\text { Krasnodarskaya } \\
\text { Kazachka }\end{array}$ \\
\hline
\end{tabular}

Analysis of the world's main cherry breeding programs has shown that they are based on five to ten main varieties, which also leads to a narrowing of the genetic base of cherry breeding $[9,10]$. This trend confirms the need to expand genetic diversity by adding new samples to the collection. The NCFSCHVW genetic collection of sweet cherry (Prunus avium L.) is mainly represented by varieties of domestic and Western European breeding. The modern cherry breeding program contains several priority areas: breeding to increase the fruit weight to world standards, reducing the strength of the tree growth, selffruitfulness, adaptability, etc. The main method of sweet cherry breeding remains intervariety hybridization within this species, interspecific hybridization between $P$. vulgaris and $P$. avium, mainly aimed at improving the quality of fruits in common cherry varieties. The spur type of fruiting is not peculiar to sweet cherry, so one of the solutions to the problem of reducing the strength of tree growth is the use of mutagenesis, by the effect of gamma rays on the vegetative buds of the plant. This method was used to obtain the improved Kavkazskaya Uluchshennaya variety (a mutant of the Kavkazskaya variety), with a restrained growth force and a compact crown. Work is also being successfully carried out in the United States, where the low-growing variety Lambert Spur (mutant of Lambert) has been isolated. Mutant varieties should be further included in the breeding to reduce the tree size (Table 3). The creation of self-fertile sweet cherry varieties is an opportunity to obtain a stable harvest even in years when the conditions for pollination may be unfavorable. It is known that the first commercial self-fertile variety was Stella $\left(\mathrm{S}_{3} \mathrm{~S}_{4}\right)$, obtained at the Research Station of the Canadian Ministry of Agriculture in Summerland [11]. Modern commercial self-produced varieties Lapins, Skeena and Sweet Hart are derived from the Stella variety. This group of varieties should be included in saturating crosses with local varieties, as well as combinations within the group should be used, in this case, there is a high probability of obtaining self-fertile varieties for growing in specific conditions.

Abnormally low winter temperatures can reduce the yield of sweet cherries, although during the period of deep rest, the sweet cherry can withstand negative temperatures in the range of $-28.0^{\circ} \ldots-30.0^{\circ} \mathrm{C}$ [5], so the "winter hardiness" trait is important for sweet cherry, since it determines the area of its possible cultivation. According to the results obtained, 
combinations of crossing with the inclusion of Melitopolskaya Chernaya and Frantsuzskaya Chernaya varieties were effective. In combination with these varieties, a greater number of winter-hardy seedlings were selected and the best domestic varieties were selected: Alaya, Volshebnitsa, Dar Izobiliya and Mak. Good results were obtained when using the Krupnoplodnaya variety as the female form, on the basis of which the Kontrastnaya and Madonna varieties with a high frost resistance potential were obtained.

The program for improving the quality of sweet cherry fruits includes several main parameters: large size, hardness, sweetness, good organoleptic indicators, which together determines high taste qualities. When improving this indicator, good results were obtained due to free pollination of local varieties Sashenka and Alaya. Good results were obtained when the Anadolskaya cherry was used as a father variety in crossing with the Napoleon Belaya sweet cherry, as a result of this combination, the Barkhatnaya and Kavkazskaya varieties with high fruit quality were obtained.

Selection of large-fruited varieties is one of the subprograms for improving the marketability and quality of sweet cherry fruits [12]. Large fruits make a major contribution to consumers' perception of high-quality products, including sweet cherry. Using local and Ukrainian varieties of Alaya, Krupnoplodnaya, Melitopolskaya Chernaya in hybridization, a series of varieties was created - Cherniye Glaza, Sashenka, Madonna, which differ in large, marketable fruits weighing 8.0-10.0 g., which allowed to enrich the group of early and medium-early varieties with large-fruited varieties, in which they were particularly lacking.

Table 3. The main directions in sweet cherry breeding in the southern region, donors and sources of valuable biological traits (city of Krasnodar, NCFSCHVW General Collection)

\begin{tabular}{|c|c|c|c|c|}
\hline Trait & Donors, sources & Country & \multicolumn{2}{|c|}{ New varieties with selected traits } \\
\hline \multirow[t]{2}{*}{$\begin{array}{l}\text { Low } \\
\text { growth }\end{array}$} & Kavkazskaya & Russia & $\begin{array}{l}\text { Kavkazskaya Uluchshennaya (mutant of } \\
\text { the Kavkazskaya variety) }\end{array}$ & Russia NCFSCHVW \\
\hline & Lambert & USA & Lambert Spur (mutant of Lambert) & USA \\
\hline \multirow{3}{*}{$\begin{array}{l}\text { Self- } \\
\text { fertility }\end{array}$} & \multirow[t]{3}{*}{ Stella $\left(\mathrm{S}_{3} \mathrm{~S}_{4}\right)$} & Canada & Lapins (Stella x Van) & Canada \\
\hline & & Canada & Skeena (Bing x Van x Stella) & Canada \\
\hline & & Canada & Sweet Hart (Van x Stella) & Canada \\
\hline \multirow[t]{6}{*}{$\begin{array}{l}\text { Winter } \\
\text { hardiness }\end{array}$} & $\begin{array}{l}\text { Frantsuzskaya } \\
\text { Chernaya }\end{array}$ & $\begin{array}{l}\text { Western } \\
\text { Europe }\end{array}$ & $\begin{array}{l}\text { Volshebnitsa (Drogana Zheltaya x Fr. } \\
\text { Chernaya) }\end{array}$ & Russia NCFSCHVW \\
\hline & \multirow{3}{*}{$\begin{array}{l}\text { Melitopolskaya } \\
\text { Chernaya }\end{array}$} & Ukraine & Alaya (Melitopolskaya Chernaya sv. op.) & Russia NCFSCHVW \\
\hline & & Ukraine & $\begin{array}{l}\text { Dar izobiliya (Mel. Chernaya x Fr. } \\
\text { Chernaya) }\end{array}$ & Russia NCFSCHVW \\
\hline & & Ukraine & Mak (Mel. Chernaya x Fr. Chernaya) & Russia NCFSCHVW \\
\hline & \multirow[t]{2}{*}{ Krupnoplodnaya } & Ukraine & Kontrastnaya (clone of Krupnoplodnaya) & Russia NCFSCHVW \\
\hline & & Ukraine & Madonna (Krupnoplodnaya sv. op.) & Russia NCFSCHVW \\
\hline \multirow{4}{*}{$\begin{array}{l}\text { Fruit } \\
\text { quality }\end{array}$} & Sashenka & Russia & Podarok Leta (Sashenka sv. op.) & Russia NCFSCHVW \\
\hline & Alaya & Russia & Cherniye Glaza (Alaya sv. op.) & Russia \\
\hline & \multirow[t]{2}{*}{$\begin{array}{l}\text { Napoleon } \\
\text { Belaya }\end{array}$} & Russia & $\begin{array}{l}\text { Kavkazskaya (Napoleon Belaya x } \\
\text { Anadolskaya cherry) }\end{array}$ & Russia NCFSCHVW \\
\hline & & Russia & $\begin{array}{l}\text { Barkhatnaya (Napoleon Belaya x } \\
\text { Anadolskaya cherry) }\end{array}$ & Russia NCFSCHVW \\
\hline \multirow{3}{*}{$\begin{array}{l}\text { Large- } \\
\text { fruitness }\end{array}$} & Alaya & Russia & Cherniye Glaza (Alaya sv. op.) & Russia NCFSCHVW \\
\hline & $\begin{array}{l}\text { Melitopolskaya } \\
\text { Chernaya }\end{array}$ & Ukraine & $\begin{array}{l}\text { Sashenka (Kavkazskaya x } \\
\text { Melitopolskaya Chernaya) }\end{array}$ & Russia NCFSCHVW \\
\hline & Krupnoplodnaya & Ukraine & Madonna (Krupnoplodnaya sv. op.) & Russia NCFSCHVW \\
\hline
\end{tabular}

\section{Conclusions}

Thus, the study of genetic collections contributes to the successful renewal of the assortment of fruit stone crops on the basis of the revealed inheritance patterns and selected 
varieties of valuable traits donors and sources. Indicators of the effective use of genetic collections are the created domestic varieties that combine a set of significant features and allow to speed up the breeding process. To date, more than 40 varieties of stone fruit crops have been created in the NCFSCHVW, including sweet cherry: Alaya, Barkhatnaya, Volshebnitsa, Dar Izobiliya, Kavkazskaya, Kavkazskaya Uluchshennaya, Podarok Leta, Madonna, Mak, Sashenka, Cherniye Glaza; cherry - Krasnodarskaya Sladkaya, Kazachka, Kirina, Kubanochka, Alexa; plum - Podruga, Charodeyka, Krasotka, Gertsog, etc., many of which are included in the Register of breeding achievements of the Russian Federation, of interest for modern breeding and cultivation in the south of Russia.

Conflict of interest. The authors declare that there is no conflict of interest. Conflict of interest. The authors declare no conflict of interest.

\section{References}

1. J. M. Al-Khayri, S. M. Jain, D. V. Johnson, Springer International Publishing AG, part of Springer Nature, 990 (2018)

2. M. Butac, V. Bozhkova, A. Zhivondov, N. Milosevic, E. Bellini, V. Nencetti, J. Blazek, E. Balsemin, B. Lafarque, et al, ISHS Acta Horticulturae 981: II Balkan Symposium on Fruit Growing, 981, 91 (2011)

3. E.N. Dzhigadlo, Improvement of breeding methods, creation of cherry and sweet cherry varieties, their rootstocks with ecological adaptation to the conditions of the Central region of Russia, 268 (2009)

4. R.Sh. Zaremuk, E.M. Alyokhina, S.V. Bogatyreva, Russian Agricultural Science, 3, 21 (2017)

5. R. Zaremuk, Y. Dolya, BIO Web of Conferences, 25(02004), 8 (2020)

6. Weifeng Wu, Faxing Chen, Kaiwun Yeh, Jianjun Chen, Biology, 8(1), 2, 13 (2019)

7. C. Petri, N. Alburquerque, M. Faize, R. Scorza, C. Dardick, Transgenic research, 27, 225 (2018)

8. R.Sh. Zaremuk, E.M. Alyokhina, S.V. Bogatyreva, Horticulture and Viticulture, 4, 15 (2016)

9. M. Schuster, H. Flachowsky, D. Köhler, Plant Breeding, 126(5), 533 (2007)

10. L.S. Rodrigues, M.R. Morales, A.J.B. Fernandes, J.M. Ortiz, Genet Resour Crop Evol, 55, 593 (2008)

11. M. Schuster, Open Agrar, 1 (2020)

12. E.M. Alyokhina, Subtropical and decorative gardening, 62, 54 (2017) 